\title{
CONCEPT OF RESILIENCE IMPLEMENTATION IN SMALL AND MEDIUM SIZED ENTERPRISES (SMES)
}

\author{
Jelena Grujić
}
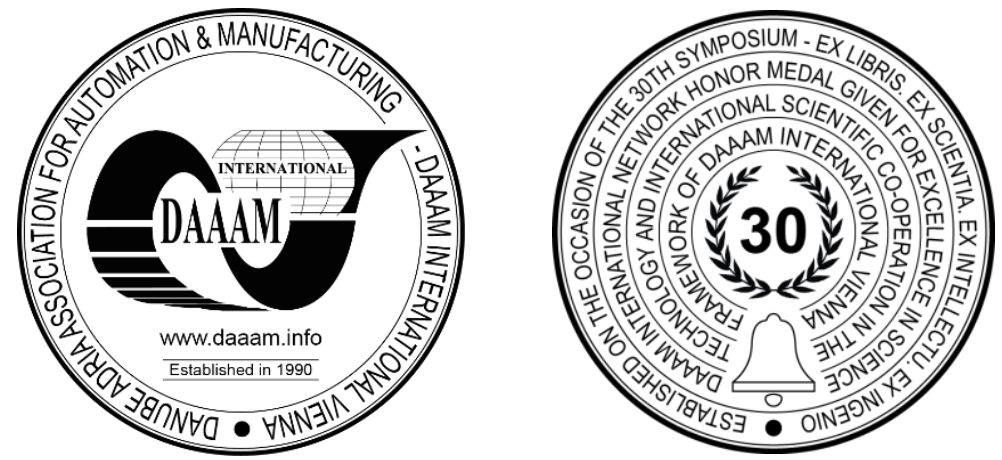

This Publication has to be referred as: Grujic, J[elena] (2019). Concept of Resilience Implementation in Small and Medium Sized Enterprises (SMEs), Proceedings of the 30th DAAAM International Symposium, pp.0839-0845, B. Katalinic (Ed.), Published by DAAAM International, ISBN 978-3-902734-22-8, ISSN 1726-9679, Vienna, Austria DOI: $10.2507 / 30$ th.daaam.proceedings.116

\begin{abstract}
This research examines response to risk factors that are present in small and medium-sized enterprises (SMEs) regarding the aspect of probability, impact and importance to their businesses. The research has included experts in the small and medium-sized enterprises running their businesses in Vojvodina. There have been considered potential threats and hazards, and models of mitigation and confrontation in the enterprises by introducing the concept of resilience. The subject of this research is implementation of resilience concept that represents a modern managing system in companies. The aim of this research is a strategic management of risk factors in SMEs including more active and efficient management implementation with risk factors that appear within the business processes. Here was applied Delphi technique as a method for data collection, evaluation and analysing.
\end{abstract}

Key words: Risk factors; Resilience; Concept; Strategy; Small and medium-sized enterprises

\section{Introduction}

In order to achieve better adaptation of small and medium-sized enterprises to the business environment and many challenges on the market, it is mandatory to introduce and develop the resilience concept into the business practice [1]. Small and medium-sized enterprises (SMEs) play a significant role in global socio economic development. Introduction of this concept into the small and medium-sized enterprises would mean increase of their ability to fight with different unpredicted situations, or ability to prevent or mitigate negative effects of risk factor that occur in their business processes. Resilience (struggle) is ability of a system to come back from disturbed position into the former (or desired) condition after certain period of time [2].

The essence of this research is management of unpredicted situations in the small and medium-sized enterprises consisting of examination of outcomes and proposal of measures for the rehabilitation and their reshaping into better quality system. The resilience is adaptive ability of one company to prepare itself for unexpected events, respond to interruptions and recover on time while maintaining operations continuity at desired level of connectivity and control of structure and function [3].

This research was conducted in order to help SMEs to discover modes of more efficient and effective business management, to avoid risky situations, increase resilience of the organization and to find out mechanisms to defend against situations endangering normal processes of functioning in the company. Introduction of the resilience concept in SMEs enables effective and efficient business management having several advantages: 
Operations will become more efficient and effective due to identification of the risk factors that can disturb the business in SMEs, and there will be undertaken activities in order to reduce probability of risky situations;

Processes will become more efficient and effective due to consideration of selective risk factors included in the process and available alternatives to cope with such factors;

Strategy of the company will become more efficient and effective when the risk factors are connected with different strategic options, and it will be possible to fully analyse obtained results providing better strategic decisions. Efficiency relates to the strategy that will be completely able to deliver desired results [4].

The resilience concept, the business of SMEs is or could be exposed to, is aimed to identify the problem on time, to examine the cause and consequence, analyse probability, impact and importance, and to monitor, control and prevent those risk factors that completely or partially disturb, or could disturb, management capacity for strategy achievement, long-term and short-term business goals and the system return into the former condition. This research was thought out as groundwork for further investigation of risk factors in small and mid-size companies. Next step of research is to expand numbers of risk factors and searching for new strategies to prevent them.

\section{Research methodology}

The first implemented step during this research work was collection of information about risky factors occurring in the business processes in SEMs. The collection of the risk factors was done on the basis of the literature research and examination of the business environment in SMEs. There were 15 small and medium-sized enterprises participated in the case study, from Vojvodina and from different sectors including agriculture, traffic, civil engineering, textile or food industry. Detailed analysis has determined risk factors that disturb business processes in SMEs. Cooperation in companies relates to ability to work efficiently with other subjects in the areas such as predicting, delay and risk distribution [5]. Here were have identified 18 risk factors the most often occur in the business processes and on the basis of which was conducted categorisation into four areas such as strategic, organizational, technological and external due to easier data processing. This is illustrated in the Table 1. Based on further examination of the business processes in SMEs there were established causes and consequences of the risk factors representing the base for further steps, and there were also established the factors that mostly prevent normal functioning of the business processes. For each risk factor there were identified several causes of occurrence with consequences defined as the final result of poor business activity. Causes and consequences are also illustrated in the Table 1.. The identification of special causes is essential for process control and further process monitoring and evaluation of the process [6]. In Future exploration it is possible to expand research with factors of risk for different companies with numerous of people who are in basic positions in concrete company. Further plan of investigation is to wide number of factors of risk and areas in which their occur.

In this research was applied Delphi technique as suitable method for risk factor evaluation in the business processes in SMEs because employees in different companies are not familiar with each other. The Delphi technique is useful for studying a wide range of research questions; it has been utilized for cultivating data and information about a topic by documenting expert or stakeholder views, recording or exploiting collective knowledge that is shared among groups of professionals, and facilitating new ways of thinking about problems and potential solutions [7]. Applied tool for the risk factor evaluation is a questionnaire. Based on the identified risk factors the questionnaire was composed of 18 risks the most repeatedly occur in SMEs. There were 54 participants answered the questionnaire in these companies. The employees offered their professional opinion evaluating probability of the risky factor occurrence, effect to goals and their importance for the company. Case of a study is limited with 18 factors of risks which were indentified, becouse it was not possible to test more people who work.

This method implementation provided certain advantage in the form of quickly achieved consensus among these participants due to their anonymity. Evaluations were in the range from 1 to 5, where 1 represents the least probability, effect and importance, and 5 represents the highest probability of effect and importance. After questioning of 15 experts in 15 SMEs, the results about risk factor assessments regarding the probability aspect, impact and importance were coordinated, and final evaluation was obtained for each risk factor. The questionnaire was then corrected [8] regarding unconformities that had occurred in the process of obtaining results in this questioning. All participants have answered the repeated questionnaire. Future studies can only be carried out with research of risk factors in one sector.

Based on summarised results, there were calculated average values taking into account answers of all participants, and the final results have emerged. They are illustrated in the Table 2. as the base for further analysis of potential threats, and methods for their resolving and the resilience concept implementation in SMEs.

After obtained results, there are applied management strategies with different risk factors aiming to reduce negative effects as produced in the business processes. By ranking of associated risks, we could specify the most important and effective claims [9].The risk presence cannot be neutralised. It is present, to higher or lower extent, and we can avoid potential consequences of failure or its probability. Decision making on risk events control in circumstances of insecurity is a type of decisions that is brought in conditions of insufficiency of adequate information, relating to the solution method or solution probability [10]. There are the following strategies of unpredicted situations management that are implemented for effective and efficient risk management in companies: risk management by avoiding - the risk is avoided when an individual does not accept the risk by not-engagement in actions leading to the risk; risk management by retaining - an individual is faced with almost unlimited risk series but does not undertake anything in that regard; risk management by 
conveying - the risk can be conveyed from one individual to another when an individual with transferred risk is faced with it; risk management by relaxing the consequences - reducing negative effects of the problem (undertaking preventive measures); risk management by reducing - the risk can be reduced by prevention and control; risk management by planning - means the plan making in case of some potential problem occurrence. Future steps of research should contain planning and developing new stategies for reducing risk factors. At the security side of risk analysis the additional arrangements can be thought as actions for minimizing of "attack area". During these analysis of the preliminary design may be taken additional arrangements in order to reduce the risk to the tolerable level [11].

In the Table 2. are proposed the measures for overcoming each individual factor by application of the following strategies: avoiding, retaining and conveying, relaxing consequences, reducing and planning the risk management. For every risk factor it was choosed strategy to overcome them, but there are limits in potentional solutions of problems. The proposed methods are just some of possibilities for the overcome of unpredicted situations, maintenance of the business continuity and flexibility at satisfying level. The flexibility creates a resilient chain of supply by increasing adaptation rate during turbulent periods [12].

\begin{tabular}{|c|c|c|c|}
\hline Risk areas & $\begin{array}{c}\text { Risky event } \\
\text { (state/phenomenon) }\end{array}$ & Cause & Consequence \\
\hline \multirow{13}{*}{ 莺 } & \multirow{4}{*}{$\begin{array}{l}\text { Do not invest in new } \\
\text { products }\end{array}$} & Poor financial situation in company & \multirow{4}{*}{ Non-competitiveness } \\
\hline & & Bad strategic orientation & \\
\hline & & Lack of personnel & \\
\hline & & Inadequate technology & \\
\hline & \multirow{3}{*}{$\begin{array}{l}\text { Narrow } \\
\text { manufacturing } \\
\text { program }\end{array}$} & Poor technology & \multirow{3}{*}{$\begin{array}{l}\text { Inferior placement on } \\
\text { the market }\end{array}$} \\
\hline & & Poor personnel & \\
\hline & & Lack of financial assets & \\
\hline & \multirow{3}{*}{$\begin{array}{l}\text { New trends in } \\
\text { product consuming }\end{array}$} & Advancement of technology & \multirow{3}{*}{ Change of business } \\
\hline & & Company strengthening & \\
\hline & & Social chances & \\
\hline & \multirow{3}{*}{$\begin{array}{l}\text { Terrible design of } \\
\text { product }\end{array}$} & Non-creative personnel & \multirow{3}{*}{$\begin{array}{l}\text { Buyers are not interested } \\
\text { in }\end{array}$} \\
\hline & & Incompetent personnel & \\
\hline & & Failure to follow up with trends & \\
\hline \multirow{10}{*}{ 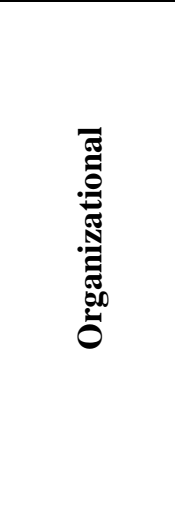 } & \multirow{2}{*}{$\begin{array}{l}\text { Incompetent } \\
\text { personnel }\end{array}$} & Lack of trainings and education for employees & \multirow{2}{*}{$\begin{array}{l}\text { Work effect in the } \\
\text { company, reduction of } \\
\text { workers`efficiency }\end{array}$} \\
\hline & & Non-adaptation of employees & \\
\hline & \multirow{3}{*}{$\begin{array}{l}\text { Unclear } \\
\text { responsibility } \\
\text { distribution }\end{array}$} & Poor interpersonal relationships & \multirow{3}{*}{ Break of cooperation } \\
\hline & & Personnel change in team & \\
\hline & & Maintaining relation with clients & \\
\hline & \multirow{3}{*}{$\begin{array}{l}\text { Poorly established } \\
\text { communication } \\
\text { channels }\end{array}$} & Mistrust of employees & \multirow{3}{*}{ Unfulfilled cooperation } \\
\hline & & Often change of employees & \\
\hline & & Unprofessional staff & \\
\hline & \multirow{2}{*}{$\begin{array}{l}\text { Inadequate } \\
\text { coordination of } \\
\text { professional staff }\end{array}$} & Poor management & \multirow{2}{*}{$\begin{array}{l}\text { Problem with } \\
\text { management }\end{array}$} \\
\hline & & Lack of skills and knowledge with managers & \\
\hline \multirow{18}{*}{ 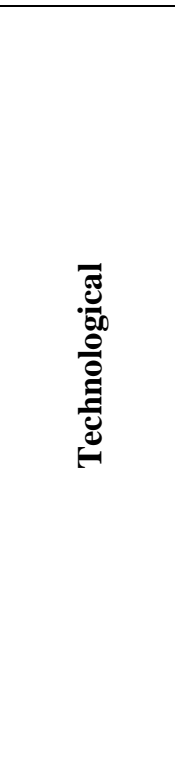 } & \multirow{3}{*}{ High price of product } & Expensive work force & \multirow{3}{*}{ Less demand of product } \\
\hline & & Expensive production material & \\
\hline & & Company policy & \\
\hline & \multirow{4}{*}{$\begin{array}{l}\text { Poorly developed } \\
\text { network of } \\
\text { distribution channels }\end{array}$} & Transportation problems & \multirow{4}{*}{$\begin{array}{l}\text { Impossible placement on } \\
\text { the market }\end{array}$} \\
\hline & & Company poor cooperation with stakeholders & \\
\hline & & Lack of financial assets & \\
\hline & & Incompetent staff & \\
\hline & \multirow{3}{*}{ Unhappy buyers } & Uninformed buyers & \multirow{3}{*}{$\begin{array}{l}\text { Competition } \\
\text { strengthening }\end{array}$} \\
\hline & & Not-fulfilled requests of buyers & \\
\hline & & Product high price & \\
\hline & \multirow{4}{*}{$\begin{array}{l}\text { Lack of technical } \\
\text { equipment }\end{array}$} & Lack of financial assets & \\
\hline & & Indifferent management & Impossibility to develop \\
\hline & & Expensive equipment & the company \\
\hline & & Unavailable equipment & \\
\hline & & Failure to adopt standards & \\
\hline & Lack or quanly & Indifferent management & Uncontrolled product \\
\hline & & Costs for control & \\
\hline & & Lack of innovativeness & \\
\hline
\end{tabular}




\begin{tabular}{|c|c|c|c|}
\hline & \multirow{2}{*}{$\begin{array}{l}\text { Non-application of } \\
\text { modern technological } \\
\text { achievements }\end{array}$} & Shortage of financial assets & \multirow{2}{*}{$\begin{array}{l}\text { Impossibility to develop } \\
\text { the company }\end{array}$} \\
\hline & & Conservative management & \\
\hline \multirow{11}{*}{ 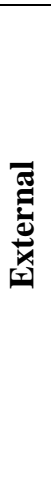 } & \multirow{3}{*}{$\begin{array}{l}\text { Change of } \\
\text { regulations }\end{array}$} & Change of government & \multirow{3}{*}{ Change of business } \\
\hline & & Coordination with European laws & \\
\hline & & Poor former regulations & \\
\hline & \multirow{2}{*}{$\begin{array}{l}\text { Political influence } \\
\text { (change of power) }\end{array}$} & Individual interests & \multirow{2}{*}{ Change of business } \\
\hline & & Political parties interests & \\
\hline & \multirow{3}{*}{$\begin{array}{l}\text { Strengthening of } \\
\text { other companies on } \\
\text { the market }\end{array}$} & Poor marketing & \multirow{3}{*}{ Buyers reduction } \\
\hline & & Narrow assortment of products & \\
\hline & & High product price & \\
\hline & \multirow{3}{*}{$\begin{array}{l}\text { Appearance of } \\
\text { substitute for } \\
\text { products }\end{array}$} & Low purchasing power with citizens & \multirow{3}{*}{$\begin{array}{l}\text { Competition } \\
\text { strengthening, buyers } \\
\text { reduction }\end{array}$} \\
\hline & & Large number of companies on the market & \\
\hline & & New product promotion & \\
\hline
\end{tabular}

Table 1. Risk factors causes and consequences in SMEs

\begin{tabular}{|c|c|c|c|c|}
\hline $\begin{array}{c}\text { Risky event } \\
\text { (state/phenomenon) }\end{array}$ & 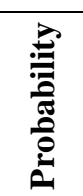 & 芯 & 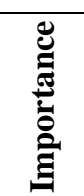 & Proposed measures to cope with \\
\hline $\begin{array}{l}\text { Not-investing in new } \\
\text { products }\end{array}$ & 2.27 & 2.00 & 3.09 & $\begin{array}{l}\text { Avoiding the risk - Maintenance of business continuity } \\
\text { (balancing economic requests in company) }\end{array}$ \\
\hline $\begin{array}{l}\text { Narrow production } \\
\text { program }\end{array}$ & 2.55 & 2.27 & 3.27 & Facing the risk - Diversification \\
\hline $\begin{array}{l}\text { New trends appearance in } \\
\text { product consumption }\end{array}$ & 2.36 & 3.45 & 2.18 & Retaining the risk - Increasing company flexibility \\
\hline Poor design of product & 3.27 & 3.45 & 3.91 & $\begin{array}{l}\text { Relaxing the risk - Increase of innovativeness, motivate } \\
\text { employees to look for and create new business ideas }\end{array}$ \\
\hline Incompetent staff & 3.72 & 4.18 & 4.64 & Conveying the risk - Engagement of team for promotions \\
\hline $\begin{array}{l}\text { Unclear distribution of } \\
\text { responsibility }\end{array}$ & 2.36 & 3.91 & 3.27 & $\begin{array}{l}\text { Relaxing the risk - Effective communication, cooperation } \\
\text { strengthening, trust building }\end{array}$ \\
\hline $\begin{array}{l}\text { Poorly established } \\
\text { communication channels }\end{array}$ & 3.27 & 4.18 & 4.45 & $\begin{array}{l}\text { Relaxing the risk - Effective communication, cooperation } \\
\text { strengthening, trust building }\end{array}$ \\
\hline $\begin{array}{l}\text { Inadequate coordination of } \\
\text { professional staff }\end{array}$ & 2.72 & 3.27 & 3.18 & $\begin{array}{l}\text { Relaxing the risk - Effective communication, cooperation } \\
\text { strengthening, trust building }\end{array}$ \\
\hline High price of product & 3.72 & 4.18 & 4.64 & $\begin{array}{l}\text { Planning the risk - Manage buyers`demand, to provide price } \\
\text { dynamics }\end{array}$ \\
\hline $\begin{array}{l}\text { Poorly developed network } \\
\text { of distribution channels }\end{array}$ & 2.45 & 3.36 & 4.45 & $\begin{array}{l}\text { Facing the risk - Increasing agility, ability to quickly respond } \\
\text { to changes }\end{array}$ \\
\hline Unsatisfaction of buyers & 2.91 & 3.45 & 3.91 & Facing the risk - To offer substitute for product \\
\hline $\begin{array}{l}\text { Lack of technical } \\
\text { equipment }\end{array}$ & 3.72 & 3.09 & 4.00 & $\begin{array}{l}\text { Avoiding the risk - Maintenance of business continuity } \\
\text { (balancing economic requests in company) }\end{array}$ \\
\hline Lack of quality control & 3.36 & 3.45 & 3.09 & Facing the risk - Organizing additional quality control \\
\hline $\begin{array}{l}\text { Failure to apply modern } \\
\text { technology achievements }\end{array}$ & 2.00 & 2.45 & 2.45 & $\begin{array}{l}\text { Avoiding the risk - Maintenance of business continuity } \\
\text { (balancing economic requests in company) }\end{array}$ \\
\hline Change of regulations & 3.00 & 3.36 & 3.09 & Retaining the risk - Increasing company flexibility \\
\hline $\begin{array}{l}\text { Political impact (change of } \\
\text { power) }\end{array}$ & 3.72 & 3.64 & 3.00 & $\begin{array}{l}\text { Relaxing the risk - Effective communication, cooperation } \\
\text { strengthening, trust building }\end{array}$ \\
\hline $\begin{array}{l}\text { Strengthening of other } \\
\text { companies on the market }\end{array}$ & 3.64 & 4.72 & 4.45 & Conveying the risk - Engagement of team for promotions \\
\hline $\begin{array}{l}\text { Appearance of substitute } \\
\text { for product }\end{array}$ & 4.00 & 3.64 & 4.55 & $\begin{array}{l}\text { Reducing the risk - Using information technologies for } \\
\text { additional information }\end{array}$ \\
\hline
\end{tabular}

Table 2. Risk factor evaluation regarding aspects of probability, impact, importance, and measures for defeating 


\section{Results and discussion}

The risk factors have been evaluated in this research work regarding aspects of probability, impact and importance in business processes in small and medium-sized enterprises. The evaluation has provided results for individual risk factors and such results were classified in categories. The risk factors with great probability (coefficient above 3.5) to occur in the business processes are incompetent staff (organizational - 3.7); high price of product (technological - 3.72); lack of technical equipment (technological - 3.72); political influence (external - 3.72), strengthening of other companies on the market (external - 3.64); and appearance of substitutes for product (external - 4.00).

The risk factors with great impact (coefficient above 3.5) to business processes are incompetent staff (organizational - 4.18); unclear distribution of responsibility (organizational - 3.91); poorly established communication channels (organizational -4.18); high price for product (technological - 4.18); political influence (external - 3.64); strengthening of other companies on the market (external -3.72); and appearance of substitutes for product (external - 3.64).

The risk factor with great importance (coefficient above 3.5) to business processes are poor design of product (strategic - 3.91); incompetent staff (organizational - 4.64); poorly established communication channels (organizational - 4.45); high price for product (technological - 4.46); poorly developed network of distribution channels (technological - 4.45); unsatisfaction of users (technological - 3.91); lack of technical equipment (technological - 4.00); strengthening of other companies on the market (external - 4.55); and appearance of substitutes for product (external - 4.55).

We can conclude, on the basis of obtained results, that the external risk factors have the highest coefficients regarding the aspects of impact and probability on the business processes in small and medium-sized enterprises. Therefore, it is mandatory to pay attention to these, and develop possible strategy on risk management for factors that belong to this group such as strengthening of other companies on the market and appearance of substitutes for product. Regarding the importance for business, the technological category has obtained the highest evaluations of risk factors: high price for product, poorly developed network of distribution channels, unsatisfaction of users, and lack of technical equipment. The organizational risk factors are also crucial when considering aspect of impact particularly including incompetent staff, unclear distribution of responsibility, and poorly established communication channels. The strategic risk factors obtained the lowest evaluation score. The risk factors with evaluation above 3.5 regarding aspects of probability, impact and importance are incompetent staff, high price of product, strengthening of other companies on the market, and appearance of substitutes for product.

The external risk factor with the highest impact, probability and importance to SMEs is strengthening of other companies on the market. Therefore, we can conclude that these companies are faced with high competition that has large impact when introducing new products on the market. In order to reduce this risk factor, it is mandatory to implement the strategy of the risk conveying, or engagement of the team of people who will work on the company position strengthening on the market. Under pressure to compete in both domestic and international markets, companies need to develop and create conditions that enable them remain competitive [13]. Existence of the substitutes for products also makes the major threat regarding the competition. It was proposed the strategy for mastering this risk factor such as risk reduction by introduction of information technologies in SMEs. The political impacts have large effects to probability of occurrence and they could be reduced using the effective communication that means strengthening the cooperation among employees. The cooperation also improves resilience enabling partners in companies to support each other during any disturbing event [14].

Incompetent staff is the organizational risk that has obtained the highest evaluation score and for its defeat it is mandatory to implement initiatives such as redesign of the business processes, management of total quality or development of new products that almost always depend on efficient and highly energetic efforts of the group [15]. The risk relaxing strategy is to be implemented to the organizational factors such as poorly established communication channels and unclear distribution of responsibility. The implementation includes more effective communication and cooperation. The communication is important to make employees to work together when managing offers in the companies [16].

The high price for the product is technological risk with the highest coefficient of probability, impact and importance for SMEs. One of the pre-conditions for preventing this risk factor is establishment of the planning strategy in a way that the company will adapt to the market requests and prepare for change of the price policy, if needed; and application of such measures will keep continuity in the business with increase of resilience. Poorly developed network of distributive channels is the risk factor that needs to be faced with while implementing agility, or capacity to respond quickly to unpredicted changes in the supply and demand [17]. Regarding technological risk factor unsatisfaction of buyers, it is mandatory to implement the strategy of facing with in a way to offer to the buyers an alternative product, and for lack of technical equipment it is necessary to maintain the business continuity.

Among strategic risks the noticeable is poor design of product that is possible to change by the strategy of factor relaxation, in a way that employees should be motivated to creatively improve products in order to satisfy consumers. The resilience is ability of the productive-distributive system to quantitatively express itself and to secure buyer`s demand on time for each product [18].

\section{Conclusion}


The risk factors were analysed here regarding the aspect of probability, impact and importance in 15 small and medium-sized enterprises that served as the base for the resilience concept implementation. The essence of conducted research means introduction of the resilience concept in a company in order to explore potential fields of hazards and effective responds to them. Small and mid size companies have many problems in their enviroment, with that in mind we have establish some strategies to improve their business. Strategies in this concept of study are adapted to reduce negative influence of 18 risk factors such as strategic, organized, technological, external and others, to be examined from aspects of probability, influence and significance. In research were proposed strategic measures which are crucial for solving issues and problems in small and mid size companies. Every risk factor were classified in appropriate area and that enable to define strategy for their overcaming.

The introduction of the resilient concept in SMEs is aimed to predict potential hazards and problems that could occur during the process steps from manufacturer to buyer, and to plan, organize and control all activities in order to successfully resolve unpredicted situations in the company and to bring it back into condition prior to the crisis occurrence. This case study is intended for small and medium-sized enterprises and all researches of risk factors in the business processes of the company. Hopefully, this research could be a benefit for the small and medium-sized enterprises because of the proposed strategies for resolving unfavourable situations that could and should be implemented in their business efforts. Plan of future research is to increase numbers of risk factors that occur, their distribution in different areas of research and to indentify more strategies to eliminate and tone down risk factors in small and mid size companies. It is neccesary to explore research with communication with workers at different levels and large number of companies divided by the sectors in which they operate.

\section{References}

[1] Fajsi, A.; Tekic, Z. \& Moraca, S. (2016). Open Innovation in Manufacturing SMEs - Integration into Value Networks, Proceedings of the 26th DAAAM International Symposium on Intelligent Manufacturing and Automation, Zadar, Croatia, , ISSN 1726-9679, ISBN 978-3-902734-07-5, Katalinic B. (Ed.), pp.1076-1081, DAAAM International, Vienna, Austria, DOI: 10.2507/26th.daaam.proceedings.151

[2] Christopher, M. \& Rutherford, C. (2004). Creating Supply Chain Resilience through Agile Six Sigma, In Critical Eye Publications, Vol. 24-28.

[3] Ponomarov, S. (2012). Antecedents and Consequences of Supply Chain Resilience: A Dynamic Capabilities Perspective, Ph.D. Dissertation, University of Tennessee,USA

[4] Berg, H. P.; (2010). Risk management: Procedures, methods and experiences, Reliability: Theory \& Applications, Bundesamt für Strahlenschutz, Salzgitter, Germany

[5] Pettit, T. J., Croxton, K. \& Fiksel, J. (2013). Ensuring Supply Chain Resilience: Development and Implementation of an Assessment Tool, Journal of Business Logistics, Vol. 34, No.1, pp. 46-76., DOI.org/10.1111/jbl.12009

[6] Bicova, K. \& Bebr, L. (2017). Identification of Special Causes, Proceedings of the 28th DAAAM International Symposium on Intelligent Manufacturing and Automation, Zadar, Croatia, ISSN 1726-9679, ISBN 978-3-90273411-2, Katalinic B. (Ed.), pp.0379-0383, DAAAM International, Vienna, Austria, DOI: 10.2507/28th.daaam.proceedings.053

[7] Franklin, K. K. \&. Hart, J. K (2007). Idea generation and exploration: Benefits and limitations of the Policy Delphi research method, Innovative Higher Education, Vol.31, pp.237-246., DOI:10.1007/s10755-006-9022-8

[8] Milunovic, S. \& Filipovic, J. (2013). Methodology for quality management of projects in manufacturing industries, Total Quality Management \& Business Excellence, Vol. 24, DOI:10.1080/14783363.2012.728851.

[9] Kremljak, Z. (2016). Risk Analysis of Specific Project Problems, Proceedings of the 27th DAAAM International International on Intelligent Manufacturing and Automation Symposium International on Intelligent Manufacturing and Automation, Zadar, Croatia, ISSN 1726-9679, ISBN 978-3-902734-08-2, Katalinic B. (Ed.), pp.0074-0081, DAAAM International, Vienna, Austria, DOI: 10.2507/27th.daaam.proceedings.011

[10] Kerzner, H.; (2003).Project Management: A System Approach to Planning, Sheduling and Controling. New York:Wiley.

[11] Stuja, K.; Poszvek, G. Wolfel, W. \& Markl, E.(2018). Integrated Method for the Design and Evaluation of Safety\& Secure Manufacturing,Proceedings of the 27th DAAAM International International on Intelligent Manufacturing and Automation Symposium International on Intelligent Manufacturing and Automation, Zadar, Croatia, ISSN 1726-9679,ISBN 978-3-902734-20-4, Katalinic B. (Ed.), pp.0157-0163, DAAAM International, Vienna, Austria DOI: $10.2507 / 29$ th.daaam.proceedings.022

[12] Christopher, M. \& Holweg, M. (2011). Supply Chain 2.0: Managing Supply Chains in the Era of Turbulence, International Journal of Physical Distribution \& Logistics Management, VOL. 41, No. 1, pp.63-82., DOI.org/10.1108/09600031111101439

[13] Mehralian, G. , Nazari, J. A., Rasekh, H. R. \& Hosseini, S. (2016). TOPSIS approach to prioritize critical success factors of TQM: Evidence from the pharmaceutical industry, The TQM Journal, Vol. 28, No.2, pp.235-249., DOI: 10.1108/TQM-03-2014-0028.

[14] Jüttner, U. \& Maklan, S. (2011). Supply Chain Resilience in the Global Financial Crisis: An Empirical Study, Supply Chain Management: An International Journal, Vol. 16, No. 4, pp.246-259., DOI.org/10.1108/13598541111139062 
[15] Drew, S. \& Coulson, C. T. (1997). Transformation through teamwork: the path to the new organization? , Team Performance Management: An International Journal, Vol.34, No.1, pp.7-17., DOI.org/10.1108/00251749610106927

[16] Mosquera, J. (2009). How to manage the threat of the global supply chain and save money, Pharmaceutical Technology Europe, Vo. 21, No.10.

[17] Christopher, M., \& Peck, H. (2004). Building the Resilient Supply Chain, The International Journal of Logistics Management, Vol. 15, No. 2, pp.1-13., DOI.org/10.1108/09574090410700275

[18] Datta, P., Christopher, M., \& Allen, P. (2007). Agent-based Modelling of Complex Production/Distribution Systems to Improve Resilience, International Journal of Logistics: Research and Applications, Vol.10, No. 3, pp.187-203., DOI.org/10.1080/13675560701467144 